\title{
Biological Characteristics and Parasitism Capacity of Telenomus podisi (Hymenoptera: Platygastridae) on Eggs of Euschistus heros (Hemiptera: Pentatomidae)
}

\author{
Gabriela Vieira Silva ${ }^{1}$, Adeney de Freitas Bueno ${ }^{2}$, Pedro Manuel Oliveira Janeiro Neves ${ }^{3} \&$ Bruna Magda Favetti ${ }^{4}$ \\ ${ }^{1}$ Centro Universitário Filadélfia, Londrina, PR, Brazil \\ ${ }^{2}$ Empresa Brasileira de Pesquisa Agropecuária, Londrina, PR, Brazil \\ ${ }^{3}$ Universidade Estadual de Londrina, Londrina, PR, Brazil \\ ${ }^{4}$ Instituto Agronômico do Paraná, Londrina, PR, Brazil \\ Correspondence: Adeney de Freitas Bueno, Empresa Brasileira de Pesquisa Agropecuária, Embrapa Soja, \\ Rodovia Carlos João Strass, Distrito de Warta-86001-970, Londrina, PR, Brazil. E-mail: \\ adeney.bueno@embrapa.br
}

Received: January 7, 2018

doi:10.5539/jas.v10n8p210

\author{
Accepted: May 27, $2018 \quad$ Online Published: July 15, 2018
}

URL: https://doi.org/10.5539/jas.v10n8p210

\begin{abstract}
We evaluated the effects of adult mating and temperature on the biological potential and parasitism of Telenomus podisi (Ashmead) (Hymenoptera: Platygastridae) on Euschistus heros (Fabricius) (Hemiptera: Pentatomidae). Females were isolated and the characteristics of the F1 generation were compared with those of females previously copulated. The parasitism capacity of $T$. podisi on E. heros eggs at $20,25,30,35$, and $40{ }^{\circ} \mathrm{C}$ was evaluated. The longevity of parental females (days), egg-adult period (days) of the F1 generation, parasitism of parental females (\%), and parasitoid emergence (\%) were not influenced by the lack or not of the copulation. The offspring of non-copulated females were males, and arrhenotokous parthenogenesis occurred. The temperatures most favorable to the parasitoid were 25 and $30^{\circ} \mathrm{C}$. Even previously copulated females generated mostly males after a few days of oviposition. Therefore, the biological characteristics and reproduction of T. podisi were impacted by adult mating prior to parasitism and by different temperatures. Although parasitism of T. podisi was not affected by mating parasitoid permanence in the field, it may be affected when unmated females are released.
\end{abstract}

Keywords: mating, arrhenotoky, biological control, temperature

\section{Introduction}

Piercing-sucking insects are one of the most important groups of arthropods that attack soybeans in South America. Those pests are noteworthy for feeding directly on the pods, thereby seriously affecting crop yields (Panizzi \& Slanky, 1985; Corrêa-Ferreira \& Azevedo, 2002). In this complex of insects belonging to the family Pentatomidae, at least 54 species have been reported from soybean-growing areas (Panizzi \& Slanky, 1985). Among them, the Neotropical brown stink bug, Euschistus heros (Fabricius) (Hemiptera: Pentatomidae), is the most abundant species, mainly in the central region of Brazil at latitudes between 0 and $23^{\circ}$ (Panizzi \& Corrêa-Ferreira, 1997). Thus, in order to mitigate losses caused by this pest and consequently increase profit, growers control this phytophagous arthropod (Zalucki et al., 2009). Currently, the primary method of pest control adopted by most soybean growers is the use of chemical insecticides (Song \& Swinton, 2009; Panizzi, 2013). However, the abuse of insecticides has brought some negative effects (Song \& Swinton, 2009), such as the rapid selection of pesticide-resistant pest strains that are resistant to a given active ingredient (Diez-Rodriguez \& Omoto, 2001; Sosa-Gómez et al., 2001; Sosa-Gómez \& Silva, 2010) or the reduction of natural biological control agents, especially when non-selective insecticides are used (Carmo et al., 2010; van Lenteren \& Bueno, 2003).

In this scenario, the use of biological control as a more sustainable form of pest management is becoming more important (van Lenteren et al., 2017). Among the natural enemies used in biological control programs, the egg parasitoid Telenomus podisi (Ashmead) (Hymenoptera: Platygastridae) has shown great potential in parasitizing eggs of E. heros (Foerster \& Queiroz, 1990; Corrêa-Ferreira \& Azevedo, 2002; Doetzer \& Foerster, 2007; van 
Lenteren et al., 2017). However, the success of $T$. podisi releases depends on an understanding of the bioecological characteristics of this parasitoid and on its interaction with the targeted host (Bourchier \& Smith, 1996). Therefore, to validate the use of T. podisi in controlling E. heros in commercial releases, laboratory studies investigating parasitoid biology and its parasitism (Hassan, 1997; Scholler \& Hassan, 2001) with biotic and abiotic factors are needed. Among those factors, mating and temperature might affect the biological characteristics of parasitoids, which could influence its efficiency in the field (Berti \& Marcano, 1991; Mcdougall \& Mills, 1997; Thomson \& Hoffmann, 2002).

All biological parameters may be highly influenced by temperature (Noldus, 1989). Therefore, the study of egg parasitoid parasitism under different temperatures is of theoretical and practical interest, as it may provide crucial information for the establishment of biological control programs for E. heros in areas having similar temperatures as those tested. Each parasitoid species may present distinct behavior according to its adaptation to these temperatures, making it more or less suitable for a specific climate condition (Bleicher \& Parra, 1989). Similarly, mating can also affect parasitoid performance (Sousa \& Spence, 2000), since recently emerged adults will focus their energy first on mating and then on parasitism. Therefore, releasing mated or unmated females can differentially impact parasitoid efficacy in the field. Thus, the objective of the present study was to evaluate the effects of adult mating and temperature on the biological potential and parasitism of $T$. podisi on E. heros eggs.

\section{Method}

\subsection{Parasitoid and Host Colonies}

Telenomus podisi females, as well as the host E. heros, used in this study originated from insect colonies kept at Embrapa Soybean, Londrina, State of Paraná, Brazil under controlled environmental conditions inside biochemical oxygen demand (BOD) climate chambers (ELETROLab®, model EL 212, São Paulo, SP, Brazil) set at $80 \pm 10 \%$ humidity, $25 \pm 2{ }^{\circ} \mathrm{C}$, and a $14 / 10 \mathrm{~h}$ photoperiod (L/D). The insects were reared following proposed by Perez and Corrêa-Ferreira (2004) and Panizzi et al. (2000), and are briefly summarized as follows.

Telenomus podisi was originally collected in soybean fields in Londrina, State of Paraná. The population was maintained in the laboratory for approximately 5 years. In the laboratory, T. podisi was reared using eggs of $E$. heros glued to pieces of cardboard $(2 \times 8 \mathrm{~cm})$ and introduced into tubes together with eggs already parasitized by T. podisi. Few drops of honey were placed inside these tubes to provide food for the adults as soon as they emerged. The tubes were then closed, and the eggs were allowed to be parasitized for $24 \mathrm{~h}$. Adults emerging from these eggs were used for trials, as well as colony maintenance.

Euschistus heros was also originally collected from soybean plants in Londrina, State of Paraná. This population was maintained in the laboratory for approximately 2 years, during which new field insects were introduced each year to maintain insect quality. The insects were kept in cages $(20 \times 20 \mathrm{~cm}$ sides $\times 24 \mathrm{~cm}$ tall $)$ made of a plastic screen and lined with filter paper. A Petri dish with a cotton wade soaked in distilled water $(9 \mathrm{~cm}$ diameter) was added to each cage. Cages were cleaned, food was replaced, and egg masses were collected three times per week. After each collection, the egg masses were transferred to acrylic boxes $(11 \times 11 \times 3.5 \mathrm{~cm})$ lined with filter paper moistened with sterile-distilled water (Gerbox $\left.{ }^{\circledR}\right)$. After eclosion, second-instar nymphs were transferred to new cages identical to those previously described. The laboratory-reared insects were then used for colony maintenance and to produce eggs for the trials.

\subsection{Bioassay 1: Influence of Mating on Telenomus podisi Parasitism}

The trial was carried out using a completely randomized experimental design with two treatments (unmated and mated females) and five replications, each composed of eight individual females $(n=40$ females/treatment $)$ inside glass tubes $(12 \times 75 \mathrm{~mm}$ tall $)$.

To obtain unmated females, E. heros eggs were offered to the parasitoids for $24 \mathrm{~h}$ in $2 \mathrm{~L}$ plastic pots for parasitism, and then the eggs were placed in individual glass tubes $(12 \times 75 \mathrm{~mm}$ tall $)$ until parasitoid emergence. After emergence, a droplet of honey was added to the glass tube to feed the adults. Some of the isolated females were placed with males for $24 \mathrm{~h}$ to copulate and some were left alone and remained unmated.

Each female was exposed to approximately $25 E$. heros eggs, which were glued to white card $(0.8 \times 5 \mathrm{~cm})$. The eggs were offered to the females for $24 \mathrm{~h}$ for parasitism. They were then removed and transferred to plastic bags $(4 \times 23 \mathrm{~cm})$ where they remained until adult emergence. Both females and cards with parasitized eggs remained under the same conditions [temperature of $25 \pm 2{ }^{\circ} \mathrm{C}, 80 \pm 10 \% \mathrm{RH}$, and $14 / 10 \mathrm{~h}$ photoperiod (L/D)]. The parameters evaluated included: the longevity of parental females (days), progeny egg-adult period (days), percentage of parasitism, emergence of parasitoids (\%), and progeny sex ratio. 


\subsection{Bioassay 2: Telenomus podisi Parasitism Capacity on Eggs of Euschistus heros Under Different Temperatures}

The trial was carried out in a completely randomized experimental design with five treatments $(20,25,30$, and $35 \pm 2{ }^{\circ} \mathrm{C}$ ) and five replicates, each one composed of six individualized females ( $\mathrm{n}=30$ females/treatment). Individual mated $T$. podisi $(\leq 48$-h old $)$ were placed into separate glass tubes $(12 \times 75 \mathrm{~mm}$ tall $)$ covered with PVC film. Droplets of pure honey on the walls of the glass tubes were offered to the females. Then, glass tubes (5 replications of 6 individualized females each) were prepared for each temperature. The tubes were then kept inside environmental chambers at temperatures of $20,25,30$, and $35 \pm 2{ }^{\circ} \mathrm{C}, 8 \pm 10 \% \mathrm{RH}$, and $14 / 10 \mathrm{~h}$ photoperiod (L/D). Eggs ( $\leq 24-h$ old) from the host colony were frozen in nitrogen liquid and prior to the trial, were unfrozen and offered for parasitism for $24 \mathrm{~h}$. These eggs were glued onto card (40 eggs each), on which the date and information of the treatment and replicate were recorded. These cards (with the eggs) were replaced daily until the death of the parasitoids. The eggs were removed daily from the glasses and maintained inside controlled environmental chambers under the same controlled conditions until the emergence of the parasitoids. The parameters recorded were: 1 ) the number of eggs parasitized per day; 2) the lifetime number of eggs parasitized per female; 3) parasitoid emergence (\%); 4) progeny sex ratio; and 5) longevity of parental females (days).

\subsection{Data Analysis}

The results obtained in the experiments were submitted to exploratory analysis to evaluate the normality assumptions of the residuals (Shapiro \& Wilk, 1965), homogeneity of variance of treatments, and additivity of the model to allow the application of ANOVA (Burr \& Foster, 1972). The lifetime number of eggs parasitized per female and the longevity of adult parasitoids when presented with the host (in bioassay 2) were transformed by the emergence (\%) of parasitized eggs by arcsine prior to the analysis of variance (ANOVA). Then, the averages were compared by Tukey test, at a 5\% error probability, using the statistical analysis program SAS (SAS Institute, 2009).

\section{Results}

\subsection{Bioassay 1: Influence of Mating Status on Telenomus podisi Parasitism}

Mating seemed to have a low effect on the evaluated characteristics of T. podisi parasitism. Longevity of parental females (days), progeny egg-adult period (days), parasitism (\%), and emergence (\%) did not differ between mated and unmated T. podisi females (Table 1). Only the progeny sex ratio differed between mated and unmated females, with $100 \%$ of progeny originating from virgin $T$. podisi females being males and only $46 \%$ of the progeny originating from the mated females being males, indicating the occurrence of arrhenotokous parthenogenesis in the absence of copulation (Table 1).

Table 1. Biological parameters of mated and unmated Telenomus podisi females that parasitized Eushistus heros eggs (bioassay 1) [temperature of $25 \pm 2{ }^{\circ} \mathrm{C}$, relative humidity of $80 \pm 10 \%$, and a photoperiod of $14 / 10 \mathrm{~h}$ (light/dark)]

\begin{tabular}{|c|c|c|c|}
\hline Females & Longevity of parental females (days) $^{1}$ & Progeny egg-adult period (days) $^{1}$ & ${\text { Parasitism }(\%)^{1}}^{1}$ \\
\hline Unmated & $18.02 \pm 2.79^{\mathrm{ns}}$ & $14.30 \pm 0.14^{\mathrm{ns}}$ & $47.84 \pm 1.86^{\mathrm{ns}}$ \\
\hline Mated & $21.57 \pm 2.09$ & $14.70 \pm 0.14$ & $48.31 \pm 3.17$ \\
\hline CV (\%) & 27.81 & 2.20 & 12.09 \\
\hline F & 1.04 & 3.91 & 0.02 \\
\hline$P$ & 0.03379 & 0.0834 & 0.9010 \\
\hline Females & Emergence $(\%)^{1}$ & Progeny sex ratio $^{1}$ & \\
\hline Unmated & $81.85 \pm 4.42^{\mathrm{ns}}$ & $0 \pm 0.0 \mathrm{a}$ & \\
\hline Mated & $82.43 \pm 2.35$ & $0.54 \pm 0.04 \mathrm{~b}$ & \\
\hline CV (\%) & 9.65 & 25.61 & \\
\hline $\mathrm{F}$ & 0.01 & 152.47 & \\
\hline$P$ & 0.9094 & $<0.001$ & \\
\hline
\end{tabular}




\subsection{Bioassay 2: Telenomus podisi Parasitism Capacity on Eggs of Euschistus heros Under Different Temperatures}

The number of parasitized eggs per day varied with temperature, but was higher on the first day of the experiment at 20,25 , and $35^{\circ} \mathrm{C}$ and on the second day of parasitism at $30^{\circ} \mathrm{C}$. The average number of eggs parasitized during the first $24 \mathrm{~h}$ was 14.3, 14, 11, and 6 at 20,25,30, and $35^{\circ} \mathrm{C}$, respectively (Figure 1). The number of daily ovipositions by parasitoids decreased as a function of parasitism time and temperature (Figure 1). Higher numbers of parasitized E. heros eggs per day were observed at all temperatures during the first 2 days of parasitism, after which, the numbers significantly decreased (Figure 1). As a result of this pattern of parasitism, T. podisi reached more than $80 \%$ lifetime parasitism on eggs of $E$. heros on days $24,15,10$, and 4 at $20,25,30$, and $35^{\circ} \mathrm{C}$, respectively (Figure 1).
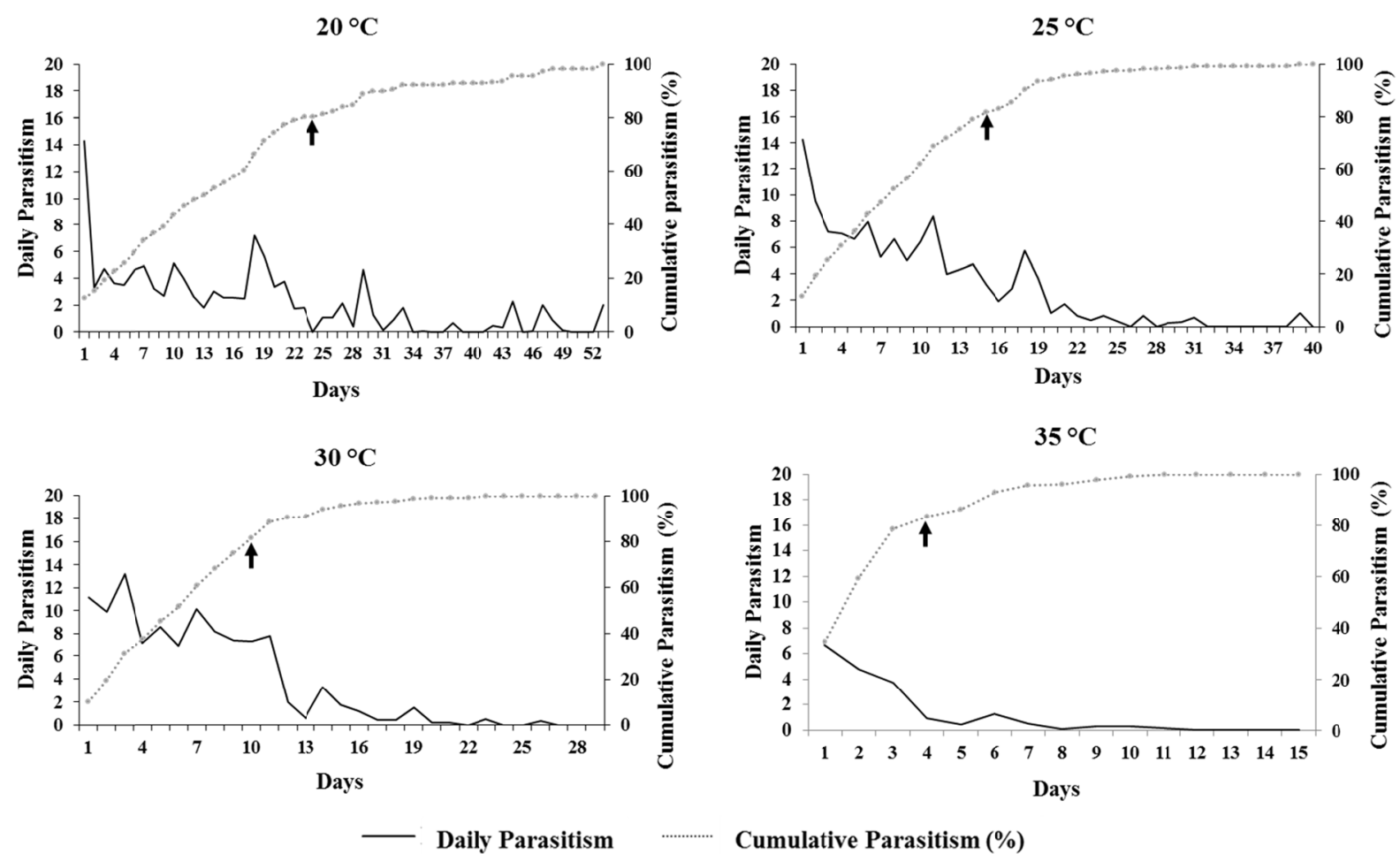

Figure 1. Daily parasitism and accumulation (\%) of Telenomus podisi in Euschistus heros eggs at different temperatures [relative humidity of $80 \pm 10 \%$, and a photoperiod of $14 / 10 \mathrm{~h}$ (light/dark)]. The arrows indicate $80 \%$ parasitism

As a combination of adult longevity and parasitoid egg load, the lifetime number of parasitized eggs varied among the temperatures (Table 2). The lifetime number of parasitized E. heros eggs by females maintained at $20{ }^{\circ} \mathrm{C}(97.47 \pm 5.37), 25^{\circ} \mathrm{C}(104.10 \pm 16.15)$, and $30^{\circ} \mathrm{C}(90.47 \pm 14.25)$ differed from the results recorded at $35{ }^{\circ} \mathrm{C}$ (18.37 \pm 1.68 ), with fewer eggs parasitized at this higher temperature (Table 2).

The emergence (\%) of parasitoids was also affected by temperature when the parasitoid was reared on eggs of $E$. heros, with the highest values observed at $30{ }^{\circ} \mathrm{C}$ and the lowest emergence observed at $35{ }^{\circ} \mathrm{C}$ (Table 2). The progeny sex ratio was directly related to the increase in temperature (Figure 2). The sex ratio was $0.35,0.37$, 0.85 , and 1.0 at $20,25,30$, and $35^{\circ} \mathrm{C}$, respectively (Table 2 ).

The longevity of parental adult T. podisi females when presented with E. heros eggs was inversely correlated with temperature (Table 2). The highest longevity was recorded at $20^{\circ} \mathrm{C}$. At 30 and $35^{\circ} \mathrm{C}$, adult parasitoids had a shorter lifespan, varying from 16.03 to 9.80 days, respectively (Table 2). 
Table 2. Telenomus podisi parasitism capacity on Euschistus heros eggs under different temperatures (bioassay 2) [relative humidity of $80 \pm 10 \%$, and a photoperiod of $14 / 10 \mathrm{~h}$ (light/dark)]

\begin{tabular}{|c|c|c|c|c|}
\hline Temperatures & $\begin{array}{l}\text { Lifetime number of eggs } \\
\text { parasitized per female }\end{array}$ & Emergence $(\%)^{1,3}$ & Progeny sex ratio ${ }^{1}$ & $\begin{array}{l}\text { Longevity of parental } \\
\text { females (days) }\end{array}$ \\
\hline $20^{\circ} \mathrm{C}$ & $97.47 \pm 5.37 \mathrm{a}$ & $35.82 \pm 2.39 \mathrm{~b}$ & $0.35 \pm 0.03 \mathrm{c}$ & $36.74 \pm 3.42 \mathrm{a}$ \\
\hline $25{ }^{\circ} \mathrm{C}$ & $104.10 \pm 16.15 \mathrm{a}$ & $25.56 \pm 2.11 \mathrm{c}$ & $0.37 \pm 0.03 \mathrm{c}$ & $20.20 \pm 2.16 b$ \\
\hline $30{ }^{\circ} \mathrm{C}$ & $90.47 \pm 14.25 \mathrm{a}$ & $50.13 \pm 0.79 \mathrm{a}$ & $0.85 \pm 0.01 \mathrm{~b}$ & $16.03 \pm 1.75 b c$ \\
\hline $35^{\circ} \mathrm{C}$ & $18.37 \pm 1.68 \mathrm{~b}$ & $0.83 \pm 0.12 \mathrm{~d}$ & $1.00 \pm 0.00 \mathrm{a}$ & $9.80 \pm 0.75 \mathrm{c}$ \\
\hline CV (\%) & 15.67 & 8.35 & 7.74 & 11.7 \\
\hline $\mathrm{F}$ & 22.14 & 245.28 & 195.69 & 28.17 \\
\hline$P$ & $<0.0001$ & $<0.0001$ & $<0.0001$ & $<0.0001$ \\
\hline
\end{tabular}

Note. ${ }^{1}$ Means \pm standard error followed by the same letter in the columns do not differ by Tukey test $(\mathrm{p} \leq 0.05) ;{ }^{2}$ Original results followed by statistics performed on $\sqrt{X}$ transformed data. ${ }^{3}$ Original results followed by statistics performed on arcsine $\sqrt{X / 100}$ transformed data; ${ }^{\text {ns }}$ ANOVA non-significant.

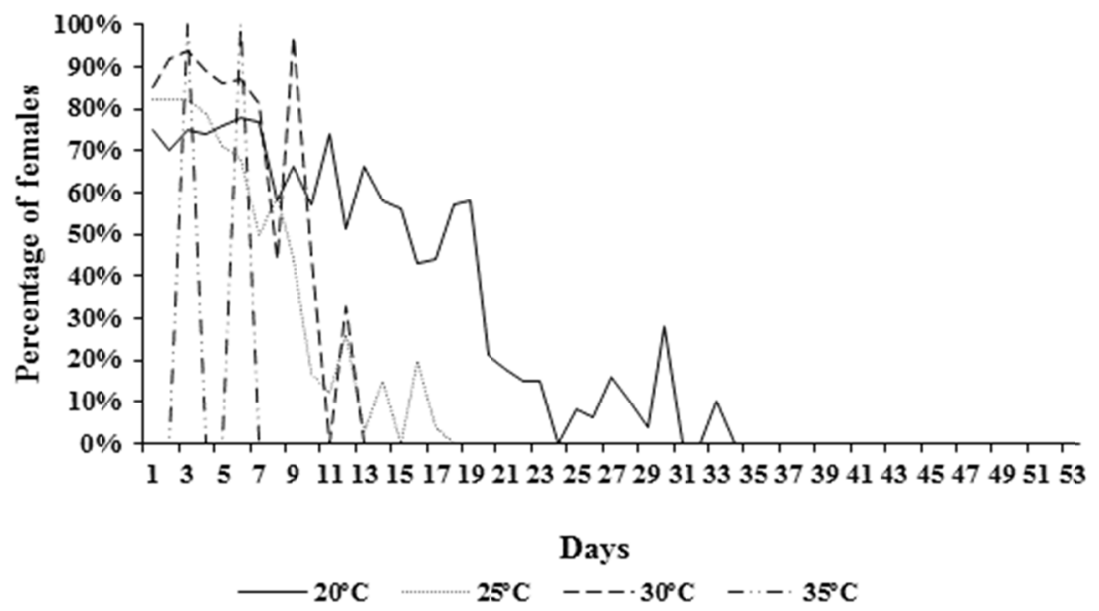

Figure 2. Sexual ratio of Telenomus podisi at different temperatures (70 $\pm 10 \% \mathrm{RH}$ and photoperiod of $14 / 10 \mathrm{~h}$ light/dark)

\section{Discussion}

Several biotic and abiotic variables might affect the biological characteristics of egg parasitoids, influencing their efficiency in the field (Mcdougall \& Mills, 1997; Thomson \& Hoffmann, 2002). A recent strategy to release egg parasitoids in the field has been to use isolated pupae that are spread over the plants, such as those of Trichogramma spp., in Brazil. However, a common behavior of $T$. podisi males, which emerge earlier than females owing to their shorter lifecycle, is to wait for females to emerge from the same parasitized egg mass (Hermel et al., 2016), allowing high mating rates directly after emergence. Therefore, the spread of T. podisi individual pupae in the field could negatively affect the reproductive behavior of the parasitoid, highlighting the importance of evaluating mating deprivation. This relationship may affect the fitness of the parasitoid when ovipositing females exploit the host eggs (Sousa \& Spence, 2000). Therefore, the importance of adult mating must be considered when releasing T. podisi, because it can compromise the maintenance of the parasitoid in the field (Pratissoli et al., 2009; Farrokhi et al., 2010), a possibility that was further evaluated in the present study.

In Hymenoptera, several species reproduce by parthenogenesis. On one hand, thelytokous parthenogenesis occurs when offspring are composed only of females, as observed in Leptocybe invasa Fisher \& La Salle (Hymenoptera: Eulophidae) (Zheng et al., 2014). On the other hand, arrhenotokous parthenogenesis occurs when the offspring are composed only of males, such as in some species of the genus Trichogramma (Hohmann et al., 2001) and Cirrospilus (Foelkel et al., 2008). For biological control programs, it is important to have more females, since they are responsible for parasitism (Navarro, 1998; Bueno et al., 2008). 
Based on the results observed in the present study, T. podisi present arrhenotokous parthenogenesis, since the absence of mating directly influenced the offspring sex ratio, leading to the production of haploid males only. Reproduction via parthenogenesis of the arrhenotoky type has been described as the most common reproductive strategy for insects in the order Hymenoptera (Pratissoli et al., 2014). However, other biological parameters were not affected. The longevity of parental females, the progeny egg-adult period, parasitism capacity (\%), and emergence of parasitoids from the parasitized eggs were similar between mated and unmated females. Queiroz et al. (2016) reported similar results for T. remus, where in progeny from mated females displayed a sex ratio of 0.6 , while it was 0 for the unmated females.

Regarding the parasitism capacity of $T$. podisi, the results illustrate that temperature interferes in all evaluated biological aspects, as previously reported for other Platygastridae species (Yeargan, 1980; Nakama \& Foerster, 2001). It is worth emphasizing that, although temperature is considered extremely important, other abiotic factors, such as relative humidity, may interfere with these biological characteristics (Parra, 1997; Pratissoli \& Parra, 2001). Another point to be considered is the specific ability of $T$. podisi to introduce the ovipositor into the corium of the host eggs once these eggs lose their turgidity following a gradual increase in temperature (Bueno et al., 2009). The possible effects of temperature on this ability can affect the quantity and uniformity of $T$. podisi parasitism, which was not recorded in our study, and should be investigated in future.

Our results, show that the lifetime number of eggs parasitized per $T$. podisi female was lower at the highest studied temperature $\left(35^{\circ} \mathrm{C}\right)$. This value is directly related to the longevity of parental adult $T$. podisi females when presented with $E$. heros eggs. It was inversely correlated with temperature. The reduced longevity of parental adults owing to increased temperature has been previously reported for different parasitoid species (Maceda et al., 2003; Hansen \& Jensen, 2002; Bourchier \& Smith, 1996; Scholler \& Hassan, 2001; Pratissoli \& Parra, 2000; Pereira et al., 2004), and determines how long T. podisi is active in the field (how long T. podisi females are parasitizing host eggs). This might vary owing to differences in temperature (Reznik \& Vaghina, 2006) or parasitoid species (Pratissoli \& Parra, 2000; Pizzol et al., 2010). Thus, it might directly influence the success of biological control programs using egg parasitoids (Smith, 1996; Wajnberg \& Hassan, 1994).

It is important to consider whether parasitism is more active during the first days of life or is evenly distributed throughout adulthood, when choosing the best parasitoid release strategy (Bueno et al., 2010). Then, those parasitoid characteristics should be considered when choosing the most suitable parasitoid species to be used in the field. The sooner the parasitoid reaches $80 \%$ of its lifetime parasitism, the better, because, while the parasitoids are exposed in the field, they might be susceptible to biotic and abiotic factors that can hinder their action. In practice, these factors might include fungicide or herbicide spraying that are necessary for crop management, or an abrupt change in temperature that can more easily kill the egg parasitoids (Carmo et al., 2010; Denis et al., 2011) but will rarely kill the pests. Egg parasitoids are usually small wasps, and are more susceptible to chemicals used in agriculture, such as herbicides and fungicides, than their hosts (Carmo et al., 2010). Furthermore, parasitoids differ from herbivorous insects by their usual inability to synthesize lipids as adults, which makes them more vulnerable to increases in temperature than most pests (Denis et al., 2011).

Although the number of parasitized eggs per day varied among the different temperatures, T. podisi oviposition peaked during the first $48 \mathrm{~h}$ of parasitism. Similar results were reported by Yeargan (1982) for T. podisi and Trissolcus euschisti (Ashmead) (Hymenoptera: Platygastridae) reared at $21{ }^{\circ} \mathrm{C}$. This biological characteristic is not only observed in Trichogrammatidae, but also in Platygastridae. Peak oviposition of egg parasitoids from the genus Trichogramma has been reported during the first day after adult emergence for several different species of this genus (Pak \& Oatman, 1982; Bai et al., 1992; Volkoff \& Daumal, 1994). This is usually because most of these egg parasitoids have the capacity to store a full complement of mature eggs in the ovaries or oviducts, and complete oogenesis either before or shortly after adult emergence (pro-ovigenic parasitoids) (Mills \& Kuhlmann, 2000) and, thus, adults emerge ready to lay eggs. In contrast, other studies have indicated that some parasitoid species emerge with an egg load that accounts for only a fraction of their potential parasitism, which exceeds their capacity to store mature eggs in their ovaries or oviducts (synovigenic parasitoids) (Houseweart et al., 1983; Smith \& Hubbes, 1986; Kuhlmann \& Mills, 1999).

Moreover, peak oviposition can vary as a consequence of pro-ovigenic or synovigenic relationships between oogenesis and oviposition, and also because of changes in parasitoid behavior (Denis et al., 2011). Adults of most Platygastridae species are incapable of lipogenesis; however, as an ectotherm insect, temperature is inversely related to their metabolic-rate and lipid consumption (Huey \& Berrigan, 2001). Thus, in those species, the allocation of lipids accumulated during the larval stage determines adult lifespan and fecundity (Visser $\&$ Ellers, 2008) and, therefore, its lifetime reproductive success (Hyey \& Berrigan, 2001). Because foraging decisions are affected by the state of external and internal variables, such as the lipid reserves and the number of 
mature eggs (Godfray, 1994) in females, lipids carried over from the larval stage can be allocated to either egg production or to adult lipid reserves, leading to a trade-off between reproduction and lifespan (Pexton \& Mayhew, 2002). This confirms the importance of this knowledge with regards the developmental rate for widespread $T$. podisi augmentative release (Butler \& Lopez, 1980). In this context, the higher number of parasitized eggs/day observed during the first $48 \mathrm{~h}$ in the present study is a positive characteristic of T. podisi.

The biological characteristics and reproduction of $T$. podisi were affected by adult mating prior to parasitism and different temperatures. Although parasitism of $T$. podisi, and therefore its control efficiency, was not affected by mating, parasitoid permanence in the field may be affected when unmated females are released. However, in augmentative biological control (ABC), parasitism capacity is more important than parasitoid maintenance in the field. Biocontrol agents are seasonally released in large numbers to rapidly reduce pests (van Lenteren et al., 2017); therefore, releasing mated females might not be important considering that the parasitism of available eggs in the field would not be affected (Carneiro et al., 2009). In addition, T. podisi exhibited high survival, as well as a high number of parasitized E. heros eggs, even at $30^{\circ} \mathrm{C}$. These results indicate that T. podisi might be well adapted to the studied temperature range $\left(20\right.$ to $\left.30^{\circ} \mathrm{C}\right)$ and, thus, be potentially suitable for use in biological control programs of E. heros in different geographical areas within this range. However, it is important to emphasize that the results presented herein are from laboratory studies, and, therefore, additional field studies are needed to fully develop a biological control program using this egg parasitoid and to confirm the hypotheses presented here.

\section{Conclusions}

The biological characteristics and reproduction of $T$. podisi were influenced by adult mating prior to parasitism and by different temperatures. Although parasitism of $T$. podisi was not affected by mating parasitoid permanence in the field, it may be affected when unmated females are released.

\section{Acknowledgements}

We thank Embrapa Soja, Conselho Nacional de Desenvolvimento Científico e Tecnológico (CNPq) and Coordenação de Aperfeiçoamento de Pessoal de Nível Superior (CAPES) for the granting of financial support and scholarships granted.

\section{References}

Bai, B., Luck, R. F., Forster, L., Stephens, B., \& Janssen, J. A. M. (1992). The effect of host size on quality attributes of the egg parasitoid, Trichogramma pretiosum. Entomologia Experimentalis et Applicata, 64, 37-48. https://doi.org/10.1111/j.1570-7458.1992.tb01592.x

Berti, J., \& Marcano, R. (1991). Effect of time of host absence on parasitism by Trichogramma pretiosum Riley (Hym.: Trichogrammatidae). Boletín de Entomología Venezolana, 6, 5-10.

Bleicher, E., Parra, J. R. P. (1989). Espécies de Trichogramma parasitoides de Alabama argillacea. I. Biologia de três populações. Pesquisa Agropecuária Brasileira, 24, 929-940.

Bourchier, R. S., \& Smith, S. M. (1996). Influence of environmental conditions and parasitoid quality on field performance of Trichogramma minutum. Entomologia Experimentalis et Applicata, 80, 461-468. https://doi.org/ 10.1111/j.1570-7458.1996.tb00960.x

Bueno, R. C. O. D. F., Carneiro, T. R., Pratissoli, D., Bueno, A. F., \& Fernandes, O. A. (2008). Biology and thermal requirements of Telenomus remus reared on fall armyworm Spodoptera frugiperda eggs. Ciência Rural, 38, 1-6. https://doi.org/10.1590/S0103-84782008000100001

Bueno, R. C. O. F., Carneiro, T. R., Bueno, A. F., Pratissoli, D., Fernandes, O. A., \& Vieira, S. S. (2010). Parasitism Capacity of Telenomus remus Nixon (Hymenoptera: Scelionidae) on Spodoptera frugiperda (Smith) (Lepidoptera: Noctuidae) Eggs. Brazilian Archives of Biology and Technology, 53, $133-139$. https://doi.org/10.1590/S1516-89132010000100017

Bueno, R. C. O. F., Parra, J. R. P., \& Bueno, A. F. (2009). Biological characteristics and thermal requirements of a Brazilian strain of the parasitoid Trichogramma pretiosum reared on eggs of Pseudoplusia includens and Anticarsia gemmatalis. Biological Control, 51, 355-361. https://doi.org/10.1016/j.biocontrol.2009.07.006

Burr, I. W., \& Foster, L. A. (1972). A test for equality of variances (p. 26). West Lafayette, University of Purdue.

Butler, G. D., \& Lopez, J. D. (1980). Trichogramma pretiosum: Development in two hosts in relation to constant and fluctuating temperatures. Annals of the Entomological Society of America, 73, 671-673. 
Carmo, E. L., Bueno, A. F., \& Bueno, R. C. O. F. (2010). Pesticide selectivity for the insect egg parasitoid Telenomus remus. BioControl, 55, 455-464. https://doi.org/10.1007/s10526-010-9269-y

Carneiro, T. R., Fernandes, O. A., \& Cruz, I. (2009). Influência da competição intra-específica entre fêmeas e da ausência de hospedeiro no parasitismo de Telenomus remus Nixon (Hymenoptera, Scelionidae) sobre ovos de Spodoptera frugiperda (J. E. Smith) (Lepidoptera, Noctuidae). Revista Brasileira de Entomologia, 53, 482-486. https://doi.org/10.1590/S0085-56262009000300026

Corrêa-Ferreira, B. S., \& Azevedo, J. (2002). Soybean seed damage by different species of stink bugs. Agricultural and Forest Entomology, 4, 145-150. https://doi.org/10.1046/j.1461-9563.2002.00136.x

Denis, D., Pierre, J. S., van Baaren, J., \& van Alphen, J. J. M. (2011). How temperature and habitat quality affect parasitoid lifetime reproductive success-A simulation study. Ecological Modelling, 222, 1604-1613. https://doi.org/10.1016/j.ecolmodel.2011.02.023

Diez-Rodriguez, G. I., \& Omoto, C. (2001). Herança da resistência de Spodoptera frugiperda (J. E. Smith) (Lepidoptera: Noctuidae) à lambda-cialotrina. Neotropical Entomology, 30, 311-316. https://doi.org/ 10.1590/S1519-566X2001000200016

Doetzer, A. K., \& Foerster, L. A. (2007). Desenvolvimento, Longevidade e Reprodução de Trissolcus basalis (Wollaston) e Telenomus podisi Ashmead (Hymenoptera: Scelionidae) em Condições Naturais durante a Entressafra da Soja no Sul do Paraná. Neotropical Entomology, 36, 233-242. https://doi.org/10.1590/ S1519-566X2007000200009

Farrokhi, S., Ashouri, A., Shirazi, J., Allahyari, H., \& Huigens, M. E. (2010). A comparative study on the functional response of Wolbachia-infected and uninfected forms of the parasitoid wasp Trichogramma brassicae. Journal of Insect Science, 10, 1-11. https://doi.org/10.1673/031.010.14127

Foelkel, E., Redaelli, L. R., Jahnke, S. M., \& Losekann, P. B. (2008). Aspectos Biológicos de Cirrospilus neotropicus Diez \& Fidalgo (Hymenoptera: Eulophidae), Parasitóide de Phyllocnistis citrella Stainton (Lepidoptera: Gracillariidae). Neotropical Entomology, 37, 279-287. https://doi.org/10.1590/S1519-566X 2008000300006

Foerster, L. A., \& Queiroz, J. M. (1990). Incidência natural de parasitismo em ovos de pentatomídeos da soja no centro-sul do Paraná. Anais da Sociedade Entomológica do Brasil, 19, 221-231.

Godfray, H. C. J. (1994). Parasitoids: Behavioural and Evolutionary Ecology (p. 473). Princeton University Press, Princeton, New Jersey.

Hansen, L. S., \& Jensen, K. M. V. (2002). Effect of temperature on parasitism and host-feeding of Trichogramma turkestanica (Hymenoptera: Trichogrammatidae) on Ephestia kuehniella (Lepidoptera: Pyralidae). Journal of Economic Entomology, 95, 50-56.

Hassan, S. A. (1997). Seleção de espécies de Trichogramma para o uso em programas de controle biológico. In J. R. P. Parra \& R. A. Zucchi (Eds.), Trichogramma e o Controle Biológico Aplicado (pp. 183-206). Piracicaba, FEALQ/USP.

Hermel, A. O., Hayashida, R., Bueno, A. F., \& Roggia, S. (2016). Preferência do parasitóide Telenomus podisi a ovos obtidos de Euchistus heros criado em laboratório ou coletado em campo. In H. S. Kern \& R. M. V. Bôas (Eds.), Resumos expandidos-XI Jornada Acadêmica da Embrapa Soja (Documentos 373, p. 252). Londrina: Embrapa Soja.

Hohmann, C. L., Luck, R. F., \& Stouthamer, R. (2001). Effect of Wolbachia on the survival and reproduction of Trichogramma kaykai Pinto and Stouthamer (Hymenoptera: Trichogrammatidae). Neotropical Entomology, 30, 607-612. https://doi.org/10.1590/S1519-566X2001000400015

Houseweart, M. W., Jennings, D. T., Welty, C., \& Southhard, S. G. (1983). Progeny production by Trichogramma minutum (Hymenoptera: Trichogrammatidae) utilizing eggs of Choristoneura fumiferana (Lepidoptera: Gelechiidae). The Canadian Entomologist, 115, 1245-1252.

Huey, R. B., \& Berrigan, D. (2001). Temperature, demography, and ectotherm fitness. The American Naturalist, 158, 204-210. https://doi.org/10.1086/321314

Kuhlmann, U., \& Mills, N. J. (1999). Comparative analysis of the reproductive attributes of three commercially-produced Trichogramma species and the influence of parasitoid size. Biocontrol Science and Technology, 9, 335-346. https://doi.org/10.1080/09583159929596 
Maceda, A., Hohmann, C. L., \& Santos, H. R. (2003). Temperature effects on Trichogramma pretiosum Riley and Trichogrammatoidea annulata De Santis. Brazilian Archives of Biology and Technology, 46, $27-32$. https://doi.org/10.1590/S1516-89132003000100005

Mcdougall, S. J., \& Mills, N. J. (1997). The influence of hosts, temperature and food sources on the longevity of Trichogramma platneri. Entomologia Experimentalis et Applicata, 83, 195-203. https://oi.org/10.1046/ j.1570-7458.1997.00172.x

Mills, N. J., \& Kuhlmann, U. (2000). The relationship between egg load and fecundity among Trichogramma parasitoids. Ecological Entomology, 25, 315-324. https://doi.org/10.1046/j.1365-2311.2000.00260.x

Nakama, P. A., \& Foerster, L. A. (2001). Efeito da Alternância de Temperaturas no Desenvolvimento e Emergência de Trissolcus basalis (Wollaston) e Telenomus podisi Ashmead (Hymenoptera: Scelionidae). Neotropical Entomology, 30, 269-275. https://doi.org/10.1590/S1519-566X2001000200010

Navarro, A. M. (1998). Trichogramma spp.: producción, uso y manejo em Colombia (p. 177). Guadalajara de Buga: Impretec.

Noldus, L. P. J. J. (1989). Semiochemicals foraging behaviour and quality of entomophagous insects for biological control. Journal of Applied Entomology, 08, 425-451.

Pak, G. A., \& Oatman, E. R. (1982). Comparative life table, behavior and competition studies of Trichogramma brevicapillum and T. pretiosum. Entomologia Experimentalis et Applicata, 32, 68-79.

Panizzi, A. R. (2013). History and Contemporary Perspectives of the Integrated Pest Management of Soybean in Brazil. Neotropical Entomology, 42, 119-127. https://doi.org/10.1007/s13744-013-0111-y.

Panizzi, A. R., \& Correa-Ferreira, B. S. (1997). Dynamics in the insect fauna adaptation to soybean in the tropics. Trends in Entomology, 1, 71-88.

Panizzi, A. R., \& Slansky, F. J. (1985). Review of phytophagous pentatomids (Hemiptera: Pentatomidae) associated with soybean in the Americas. Florida Entomologist, 68, 184-203.

Panizzi, A. R., McPherson, J. E., James, D. G., Javahery, M., \& McPherson, R. M. (2000). Stink bugs (Pentatomidae). In C. W. Schaefer \& A. R. Panizzi (Eds.), Heteroptera of economic importance (pp. 432-434). Boca Raton, Florida, USA: CRC.

Parra, J. R. P. (1997). Técnicas de criação de Anagasta kuehniella, hospedeiro alternativo para produção de Trichogramma. In J. R. P. Parra \& R. A. Zucchi (Eds.), Trichogramma e o controle biológico aplicado (pp. 121-150). Piracicaba, FEALQ/USP.

Pereira, F. F., Barros, R., Pratissoli, D., \& Parra, J. R. P. (2004). Biologia e exigências térmicas de Trichogramma pretiosum Riley e T. exiguum Pinto \& Planter (Hymenoptera: Trichogrammatidae) criados em ovos de Plutella xylostella (L.) (Lepidoptera: Plutellidae). Neotropical Entomology, 33, 231-236. https://doi.org/ 10.1590/S1519-566X2004000200014

Peres, W. A. A., \& Corrêa-Ferreira, B. S. (2004). Methodology of mass multiplication of Telenomus podisi Ash. and Trissolcus basalis (Woll.) (Hymenoptera: Scelionidae) on eggs of Euschistus heros (Fab.) (Hemiptera: Pentatomidae). Neotropical Entomology, 33, 457-462. https://doi.org/10.1590/S1519-566X2004000400010

Pexton, J. J., \& Mayhew, P. J. (2002). Siblicide and life-history evoluation in parasitoids. Behavioral Ecology, 13, 690-695. https://doi.org/10.1093/beheco/13.5.690

Pizzol, J., Pintureau, B., Khoualdia, O., \& Desneux, N. (2010). Temperature-dependent differences in biological traits between two strains of Trichogramma cacoeciae (Hymenoptera: Trichogrammatidae). Journal of Pest Science, 83, 447-452. https://doi.org/10.1007/s10340-010-0327-0

Pratissoli, D., \& Parra, J. R. P. (2000). Desenvolvimento e exigências térmicas de Trichogramma pretiosum Riley, criados em duas traças do tomateiro. Pesquisa Agropecuária Brasileira, 35, 1281-1288. https://doi.org/ 10.1590/S0100-204X2000000700001

Pratissoli, D., \& Parra, J. R. P. (2001). Seleção de linhagens de Trichogramma pretiosum Riley (Hymenoptera: Trichogrammatidae) para o controle das traças Tuta absoluta (Meyrick) e Phthorimaea opercullella (Zeller) (Lepidoptera: Gelechiidae). Neotropical Entomology, 30, 277-282. https://doi.org/10.1590/S1519-566X 2001000200011 
Pratissoli, D., Kloss, T. G., Zinger, F. D., Carvalho, J. R., Vianna, U. R., \& Paes, J. P. (2014). Does mating interfere in the biological characteristics of a population of Trichogramma pretiosum? Anais da Academia Brasileira de Ciências, 86, 459-464. https://doi.org/10.1590/0001-3765201496712

Pratissoli, D., Oliveira, H. N. D., Polanczyk, R. A., Holtz, A. M., Bueno, R. C. O. F., Bueno, A. F., \& Gonçalvez, J. R. (2009). Adult feeding and mating effects on the biological potential and parasitism of Trichogramma pretiosum and T. acacioi (Hymenoptera: Trichogrammatidae). Brazilian Archives of Biology and Technology, 52, 1057-1062. https://doi.org/10.1590/S1516-89132009000500001

Queiroz, A. P., Bueno, A. F., Pomari-Fernandes, A., Bortolotto, O. C., Mikami, A. Y., \& Olivee, L. (2016). Influence of host preference, mating, and release density on the parasitism of Telenomus remus (Nixon) (Hymenoptera, Platygastridae). Revista Brasileira de Entomologia, 61, 86-90. https://doi.org/10.1016/ j.rbe.2016.12.004

Reznik, S. Ya., \& Vaghina, N. P. (2006). Temperature effects on induction of parasitization by females of Trichogramma principium (Hymenoptera, Trichogrammatidae). Entomological Review, 86, 133-138. https://doi.org/10.1134/S0013873806020023

SAS Institute. (2001). User's Guide: Statistics (Version 8e). SAS Institute, Cary, NC.

Scholler, M., \& Hassan, S. A. (2001). Comparative biology and life tables of Trichogramma evanescens and T. cacoeciae with Ephestia elutella as host at four constant temperatures. Entomologia Experimentalis et Applicata, 98, 35-40. https://doi.org/10.1046/j.1570-7458.2001.00754.x

Shapiro, S. S., \& Wilk, M. B. (1965). An analysys of variance test for normality (complete samples). Biometrika, $52,591-611$.

Smith, S. M. (1996). Biological control with Trichogramma: Advances, successes, and potencial of their use. Annual Review of Entomology, 41, 375-406.

Smith, S. M., \& Hubbes, M. (1986). Strains of the egg parasitoids Trichogramma minutum Riley. II. Utilization for release against the spruce budworm. Journal of Applied Entomology, 102, 81-93.

Song, F., Swinton, S. M. (2009). Returns to integrated pest management research and outreach for soybean aphid. Journal of Economic Entomology, 102, 2116-2125. https://doi.org/10.1603/029.102.0615

Sosa-Gómez, D. R., \& Silva, J. J. (2010). Neotropical brown stink bug (Euschistus heros) resistance to methamidophos in Paraná, Brazil. Pesquisa Agropecuária Brasileira, 45, 767-769. https://doi.org/ 10.1590/S0100-204X2010000700019

Sosa-Gomez, D. R., Corso, I. C., \& Morales, L. (2001). Insecticide Resistance to Endosulfan, Monocrotophos and Metamidophos in the Neotropical Brown Stink Bug, Euschistus heros (F.). Neotropical Entomology, 30, 317-320. https://doi.org/10.1590/S1519-566X2001000200017

Sousa, J. M., \& Spence, J. R. (2000). Effects of Mating Status and Parasitoid Density on Superparasitism and Offspring Fitness in Tiphodytes gerriphagus (Hymenoptera: Scelionidae). Annals of the Entomological Society of America, 93, 548-553. https://doi.org/10.1603/0013-8746(2000)093[0548:EOMSAP]2.0.CO;2

Thomson, L. J., \& Hoffmann, A. A. (2002). Laboratory fecundity as predictor of field success in Trichogramma carverae (Hymenoptera: Trichogrammatidae). Journal of Economic Entomology, 95, 912-917. https://doi.org/10.1093/jee/95.5.912

van Lenteren, J. C., \& Bueno, V. H. P. (2003). Augmentative biological control of arthropods in Latin América. Biocontrol, 48, 123-139. https://doi.org/10.1023/A:1022645210394

van Lenteren, J. C., Bolckmans, K., Kohl, J., Ravensberg, W. J., \& Urbaneja, A. (2017). Biological control using invertebrates and microorganisms: Plenty of new opportunities. BioControl, 62, 1-25. https://doi.org/ 10.1007/s10526-017-9801-4

Visser, B., \& Ellers, J. (2008). Lack of lipogenesis in parasitoids: A review of physiological mechanisms and evolutionary implications. Journal of Insect Physiology, 54, 1315-1322.

Volkoff, A. N., \& Daumal, J. (1994). Ovarian cycle in immature and adult stages of Trichogramma cacoeciae and T. brassicae (Hym. Trichogrammatidae). Entomophaga, 39, 303-312.

Wajnberg, E., \& Hassan, S. A. (1994). Biological control with egg parasitoids (p. 286). British Library, Wallingford. 
Yeargan, K. V. (1980). Effects of temperature on developmental rate of Telonomus podisi (Hymenoptera: Scelionidae). Annals of the Entomological Society of America, 73, 339-342.

Yeargan, K. V. (1982). Reproductive capability and longevity of the parasitic wasps Telenomus podisi and Trissolcus euschisti. Annals of the Entomological Society of America, 75, 181-183.

Zalucki, M. P., Adamson, D., \& Furlong, M. J. (2009). The future of IPM: Whither or wither? Australian Journal of Entomology, 48, 85-96. https://doi.org/10.1111/j.1440-6055.2009.00690.x

Zheng, X. L., Li, J., Yang, Z. D., Xian, Z. H., Wei, J. G., Lei, C. L., ... Lu, W. (2014). A review of invasive biology, prevalence and management of Leptocybe invasa Fisher \& La Salle (Hymenoptera: Eulophidae: Tetrastichinae). African Entomology, 22, 68-79. https://doi.org/10.4001/003.022.0133

\section{Copyrights}

Copyright for this article is retained by the author (s), with first publication rights granted to the journal.

This is an open-access article distributed under the terms and conditions of the Creative Commons Attribution license (http://creativecommons.org/licenses/by/4.0/). 